DOI $10.4467 / 2543733$ XSSB.17.030.8328

\title{
POSZUKIWANIE TOŻSAMOŚCI WSPÓLNOTOWEJ A SAMOIDENTYFIKACJA ETNICZNA MIESZKAŃCÓW BOŚNI I HERCEGOWINY W ŚWIETLE LITERATURY
}

Słowa kluczowe: tożsamość etniczna, tożsamość narodowa, Bośnia i Hercegowina, Emir Kusturica, Miljenko Jergović

Bośnia i Hercegowina, którą jeszcze w XIX wieku przybysze z Francji i Anglii zwali „słowiańską Szwajcarią,", w opinii badaczy pozostawała ${ }^{2}$ i pozostaje nadal przestrzenią zróżnicowaną pod względem etnicznym i kulturowym, która może generować dalsze niepokoje i prowadzić do konfliktów ${ }^{3}$. Dla analityków opisujących sytuację w trakcie krwawej wojny lat 1992-1995 - podobnie jak całe Bałkany stygmatyzowane frazami

${ }^{1}$ M. Czermiń s ki, Z podróży po Bośni i Hercegowinie. Kraków 1899, s. 4.

2 Zob. m.in.: L. Prós zyński, Bośnia i Hercegowina. Treściwe opisanie tych krajów pod względem topograficznym, etnograficznym, statystycznym i historycznym. Przyczynek do ziemioznawstwa pobratymczych nam ludów południowo-zachodniej Słowiańszczyzny, Warszawa, 1882; H. B a tow s ki, Problem bośniacki Podstawy historyczne, „Prace Komisji Środkowoeuropejskiej” PAU, 1994, t. II, s. 21-37; D. Wy br a n o w s k i, Między niepodległościa a dezintegracją. Bośnia i Hercegowina w XX i XXI wieku, Szczecin 2011; J. Muś, Bośnia i Hercegowina. Etnopolityczne podziały i ich uwarunkowania, Lublin 2013; M. S a vić-B oj a n ić, Minority Discontent as an Internal Destabilization Factor: The Issue of Territorial Minorities in Bosnia and Hercegovina, [w:] Bałkany Zachodnie w systemie bezpieczeństwa euroatlantyckiego, red. A. Głowacki, S. L. Szczesio, Łódź 2015, s. 459-483.

3 „Bośnia i Hercegowina ani nie stała się państwem w pełni stabilnym i przewidywalnym, spełniającym wymogi nowoczesnej demokracji, ani też nie doszło do eskalacji konfliktu i zerwania kruchego porozumienia. Bez wątpienia jest to kraj na rozdrożu, który wprawdzie istnieje, uznała go wspólnota międzynarodowa, jest członkiem wielu organizacji i nawet odgrywa w nich ważną rolę (np. wchodzi w skład Rady Bezpieczeństwa ONZ), ale jego struktura opiera się na dysfunkcjonalnych rozwiązaniach, ponadto naruszających powszechnie uznane prawa człowieka i obywatela". Zob.: K. Krys i en i el, W cieniu Dayton. Bośnia i Hercegowina między etnokracja i demokracja konsocjonalna, Warszawa 2012, s. 373. Zob. też: J. I1 ić, Characteristics and Importance of some Etno-national and Political-geographic factors relevant for the possible political-legal disintegration of Yugoslavia, [w:] The creation and changes of the internal borders of Yugoslavia, ed. S. Ivanović, Belgrad 1991, s. 69-94.

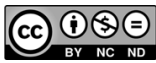


„beczka prochu” czy „kocioł bałkański” - Bośnia i Hercegowina stała się przykładem regionu Europy opanowanego przez niebezpieczną i groźną chorobę, rozprzestrzeniającą się na nowe terytoria, chorobę, którą stanowić miała idea państwa czystego etnicznie ${ }^{4}$.

Po rozpadzie Jugosławii jej mieszkańcy stanęli przed osobistymi wyzwaniami - była to nie tylko konieczność odnalezienia siebie w nowych okolicznościach, ale także przymus deklaratywnego określania, kim się jest. Po okresie trwania państwa federacyjnego w Bośni i Hercegowinie, zgodnie z koncepcją unitarystyczno-centralistyczną, określano się często wyznacznikiem narodowościowym Jugosłowianin, co stanowiło składową procesu wtapiania się w większe jednostki narodowe dla uniknięcia nacisków nacjonalistycznych ${ }^{5}$. W wyniku rozpadu państwa i krwawego konfliktu w BiH jej mieszkańcy musieli dokonać wyboru swojej tożsamości. $Z$ tego też powodu, na potrzeby niniejszego tekstu, tożsamość jest tu ujmowana w szerokim kontekście stosunku człowieka do samego siebie i stosunku do innych ludzi, a więc do kultury i tradycji, wskazując na związek opierający się na mniej lub bardziej świadomych postawach wobec wartości, których nosicielem jest zarówno sam podmiot, jak i inni ludzie oraz kultura. Pojemność terminu, w którym zawierać się mogą kategorie tożsamości wspólnotowej, etnicznej, religijnej, narodowej, kulturowej ${ }^{6}$, zwraca uwagę na jego skomplikowaną strukturę. Sama tożsamość staje się bowiem problemem, a jej pojęcie - odnoszone do świata społecznego, tworzy zbiór właściwości opisujących istotne cechy podmiotu w jego własnych przekonaniach ${ }^{7}$. Próba jej rozpatrywania na wybranych przykładach indywidualnych - znanych postaci wywodzących się z Bośni i Hercegowiny - skutkuje konstatacją, że doświadczenie tożsamości indywidualnej jest nierozerwalnie związane ze świadomością przynależności do pewnej tradycji i kultury. Problem egzystencjalny uczestnika życia społecznego demonstruje i komunikuje działania dotyczące tejże tożsamości w wyniku przemian następujących w dotychczasowym otoczeniu. Dla zobrazowania tak ujmowanej kwestii tożsamości, prowadzącej w skali społecznej do indywidualnych wyborów, w efekcie których dochodzi do zmiany własnej samoidentyfikacji ${ }^{8}$, posłużono się tu przykładem dwóch współczesnych autorów wywodzących się z Sarajewa ${ }^{9}$ - Serba Emira Kusturicy i Chorwata Miljenko Jergovicia. W ich utworach, na bazie przeżyć własnych pisarzy, ukazana została zmienność kolei losów mieszkańców Bośni i Hercegowiny. Postępujące przemiany, uwarunkowane rozpadem Jugosławii i krwawą wojną, zwieńczało zawarcie pokoju w Dayton, wymuszając poszukiwanie własnej tożsamości. Następstwem brutalnych wydarzeń - niszczących świat ich młodości, dojrzewania i części dorosłego życia w atmosferze pokojowego, a nawet przy-

${ }^{4}$ Piszę o tym w tekście: Polska wizja bałkańskiej przestrzeni terytorialnej w kontekście pojęcia , kociot batkański”, „Slavia Meridionalis”, 2007, t. 7, s. 168-169.

${ }^{5}$ A. Ja gi ełło-Szostak, Komuniści jugostowiańscy wobec idei i tożsamości jugostowiańskiej, „Balcanica Posnaniensia", 2013, t. XX, s. 185.

${ }^{6} \mathrm{Na}$ mnogość definicji tożsamości zwraca uwagę Barbara Czapik-Lityńska, Etniczny wymiar ponowoczesnej tożsamości kulturowej, [w:] Czytać. Wędrować. Być. Tom dedykowany Profesorowi Zdzistawowi Daraszowi, red. M. Bogusławska, J. Goszczyńska, J. Šuler-Galos, Warszawa 2016, s. 113-116.

${ }^{7}$ Z. B o k s zań s k i, Tożsamości zbiorowe, Warszawa 2006, s. 17; D. Łu g o w s ka, Zasada trójzgodności. Analiza kontekstowa treści pojęcia jedność, Warszawa 2013, s. 164-168.

${ }^{8}$ Ibidem, s. 19.

${ }^{9}$ Pomijam tu twórców zaliczanych obecnie do narodu Boszniaków i manifestujących swą boszniacką tożsamość z prozaicznego powodu - autorzy ci mieszkają na terenie Bośni i Hercegowiny i współtworzą model kształtujący nowe formy bośniacko-muzułmańskiego komponentu wewnątrz wielokulturowego organizmu $\mathrm{BiH}$. 
jacielskiego współistnienia pośród odmiennych etnosów - była konieczność określenia samego siebie w nowych środowiskach i nowych miejscach (Chorwacja, Serbia). Po zmianie istniejącego porządku okazało się, że obowiązująca za czasów titowskiej Jugosławii doktryna braterstwa i jedności, realizowana przez stworzony etnonim narodowościowy „Jugosłowianin”, wraz z państwowym ateizmem przestały obowiązywać, a przynależność konfesyjna oraz alfabet stały się podstawowymi determinantami wyznaczającymi przynależność etniczną i narodową.

Opis procesu określania swojej tożsamości zawierają teksty Gdzie ja jestem w tej historii? Emira Kusturicy ${ }^{10}$ i Ojciec Miljenko Jergovicia ${ }^{11}$. Utwory prezentują różne, choć zbliżone gatunki literackie, powieść wspomnieniową i autobiografię. W oparciu o zasadę literaturoznawczą obydwa stanowią formę podawczą epiki, która w ujęciu literackim opisuje pewien wycinek rzeczywistości ${ }^{12}$.

Pozwalają one dokonać porównania, w jaki sposób w wielokulturowym społeczeństwie Bośni i Hercegowiny doby federacyjnej Jugosławii manifestowano bądź odrzucano samoidentyfikację etniczną oraz w jaki sposób tożsamość byłych mieszkańców Sarajewa określana i manifestowana jest obecnie. W tym celu konieczne jest przyjęcie perspektywy czasowej, odnoszącej się do okresu titowskiej Jugosławii z jej ideą braterstwa i jedności, jako czasu względnej stabilizacji i wspólnoty państwowej, która scalać miała w jednym organizmie wszystkie zróżnicowane etnosy. Wyniszczająca wojna lat 90. w Bośni i Hercegowinie, zakończona porozumieniem zawartym w rezultacie misji pokojowych ONZ, wykreowała nowe realia, które ujawniły skutki polityki prowadzonej przez Josipa Broz Titę, tworzącego państwo ponadetniczne ${ }^{13}$. Jak skonstatował kilka lat po Dayton bośniacki humanista Vedad Spahić ,okres życia w ramach wspólnoty jugosłowiańskiej był swoistą kwarantanną dla wielu problemów", szczególnie w sytuacji Bośni i Hercegowiny jako kraju, którego „wielokulturowość i wielowyznaniowość mają tysiącletnią tradycję"14.

Po okresie rozwoju BiH za czasów Tity, kiedy rozmywane było poczucie przynależności etnicznej, nastąpiła eksplozja etniczności. Choć pokojowe mediacje doprowadziły do względnej stabilizacji, to jednak postępujący kryzys gospodarczy nie sprzyjał i nie sprzyja trwałemu poczuciu równowagi pomiędzy zróżnicowanymi etnosami w kantonalnym obecnie kraju ${ }^{15}$. Jak pokazują uwarunkowania współczesnego państwa, zaprowadzenie idei unifikacyjnej, która przyświecała politykom zmierzającym do zawarcia porozumienia w Dayton, wciąż pozostaje utopią nie tylko w wymiarze symboliki państwowej - godła i flagi. Te, narzucone z zewnątrz, nie posiadały swoich wcześniejszych odpowiedników, a miały pogodzić zróżnicowane etnosy - Serbów, Chorwatów i wyznawców islamu,

${ }^{10}$ E. Ku s turi c a, Gdzie ja jestem w tej historii?, tłum. G. Hałat, M. Goreń, Warszawa 2014.

11 Powieść ukazała się w Zagrzebiu w 2010 roku pod tytułem Otac. Tu korzystam z jej polskiego przekładu: M. J e rg o vi ć, Ojciec, tłum. M. Petryńska, Wołowiec 2012.

12 S. Sierotwiński, Słownik terminów literackich, Wrocław-Warszawa 1986, s. 71 (epika), s. 166 (pamiętnik).

${ }_{13}$ P. Ti mo fi j ju k, Ustrój polityczny Republiki Bośni i Hercegowiny w myśl porozumień z Dayton, [w:] Bałkany. Etnokulturowe podłoże konfliktów, red. W. Konarski, A. Koseski, Pułtusk 2006, s. 147-186.

${ }_{14}$ V. S p a h i ć, Bośniacko-muzulmańska tożsamość kulturowa między zasadami mocy i pokoju, [w:] Wokót Macedonii: siła kultury - kultura siły, red. B. Zi e li ń s k i, Poznań 2002, s. 221, 229.

15 Zob. K. Kry s i en i e 1, Kryzys gospodarczy w Bośni i Hercegowinie i jego wplyw na stabilność państwa (wybrane aspekty), [w:] Bałkany Zachodnie w systemie bezpieczeństwa euroatlantyckiego, red. A. Głowacki, S. L. Szczesio, Łódź 2015, s. 439-458. 
Boszniaków. Godło państwowe $\mathrm{BiH}$, z dominującą barwą ciemnoniebieską - jak podkreśla się w oficjalnych objaśnieniach symboliki - przyjmuje ów niebieski jako kolor nadziei. W ten sposób ma nawiązywać także do znaczących wspólnot państwowych, stabilnego współżycia zróżnicowanych etnosów i włączania się nowego państwa do struktur UE oraz NATO. Pięć całych i dwie połówki srebrnych gwiazd, przebiegające po przekątnej, mają podkreślać cywilizacyjną i kulturową przynależność Bośni i Hercegowiny do Europy i kręgu współczesnych narodów i państw europejskich ${ }^{16}$. Powielająca te same elementy flaga państwowa nie ma żadnych wcześniejszych analogii, a została narzucona drogą ugody politycznej z 4 lutego 1998 roku. O jej przyjęciu zadecydowało stanowisko mediacyjne hiszpańskiego dyplomaty Carlosa Westendorpa, Wysokiego Przedstawiciela ONZ dla Bośni i Hercegowiny w latach 1997-1999. Choć flaga i godło zostały oficjalnie zaakceptowane przez parlament $\mathrm{w}$ roku 2001, to nadal problemem pozostaje oficjalny hymn państwowy, który miałby jednoczyć wszystkich mieszkańców nowego państwa. Jeszcze w połowie 1998 roku Urząd Wysokiego Przedstawiciela ONZ dla BiH ogłosił konkurs na hymn państwowy. Z kilkudziesięciu propozycji, jakie wpłynęły do rozpatrzenia przez parlament, uwzględniono trzy projekty. I tak jego decyzją z 10 lutego 1999 przyjęto melodię Intermezzo, autorstwa Dušana Šesticia, zmieniając w ten sposób hymn obowiązujący w latach 1995-1998 Jedna i jedina, wykonywany podczas rozgrywek sportowych ${ }^{17}$. Do tej pory hymn istnieje tylko w wersji instrumentalnej. Wszelkie próby dopasowania tekstu do muzyki, która i tak z czasem okazała się plagiatem linii melodycznej z amerykańskiego filmu z 1978 roku (National Lampoon's Animal House), wywołuje zwykle protesty poszczególnych etnosów. Problemu nie rozwiązał także przeprowadzony w roku 2008 konkurs na słowa hymnu. Mimo ogromnej liczby zgłoszeń (339) i rekomendacji, parlament nie zaakceptował żadnego z proponowanych projektów. Sprowokowało to użytkowników sieci internetowej do swoistej rywalizacji w zamieszczaniu tamże własnych wersji tekstów hymnu, od wariantów prześmiewczych po poważne ${ }^{18}$.

Kwestie problematyczne kantonalnego państwa przebiegają również w warstwie życia codziennego, wywołując zwykle sprzeciw któregoś z etnosów, określających się jako Serbowie, Chorwaci czy Boszniacy. Jednym z ostatnich problematycznych przykładów, dowodzących, że nie można mówić o tożsamości wspólnotowej $\mathrm{BiH}$, okazała się decyzja Serbów bośniackich dotycząca zwołania referendum o ustanowieniu ich święta państwowego. Zgromadzenie Narodowe w Republice Serbskiej BiH przegłosowało jego przeprowadzenie wbrew temu, że Sąd Konstytucyjny uznał je za niekonstytucyjne i dyskryminujące pozostałe narodowości. Prezydent Republiki Serbskiej Milorad Dodik ogłosił w Banja Luce głosowanie w sprawie Dnia Republiki Serbskiej, które miałoby przypadać co roku 9 stycznia, upamiętniając w ten sposób rocznicę ustanowienia republiki w 1992

${ }^{16}$ L. Mor o z-Grze la k, Emblematyczne formy manifestowania wartości w świecie postjugosłowiańskim. Patriotyzm, [w:] Konstrukcje i destrukcje tożsamości. Wartości w świecie słowiańskim, red. E. Golachowska, D. Pazio-Wlazłowska, Warszawa 2015, s. 363-364.

${ }_{17}$ Zob.: http://www.avaz.ba/clanak/249336/himna-bih-predmet-sprdnje-na-americkim-socijalnim-mrezama?url=clanak/249336/himna-bih-predmet-sprdnje-na-americkim-socijalnim-mrezama. (dostęp: 20.08.2016).

${ }_{18}$ Poza wariantami anonimowymi podawane są autorskie wersje tekstów podkładanych do obowiazującej linii melodycznej. Przykład z 2011 r., który miałby uchodzić za poważny, zamieścił np. Malden Kaurin: http://www.dailymotion.com/video/x2zdzai. Wariant ocierajacy sie o groteskę upublicznił Zoka Ćatić: http:// www.krajina.ba/171692/himna-bih-dobila-tekst-poslusajte-kako-sada-zvuci-himna-bosne-i-hercegovine/, (dostęp: 8. 08.2016). 
roku i łącząc je ze świętem cerkiewnym św. Stefana. Decyzja o referendum w tej sprawie została uznana nie tylko za dyskryminującą pozostałe etnosy, ale także za naruszającą ustalenia pokojowe z Dayton ${ }^{19}$. Natomiast sami Serbowie, jak donoszono w komunikatach prasowych, zostali podzieleni, gdyż niektórzy z nich uznali, iż referendum jest marnotrawstwem pieniędzy, a ponadto wpisuje się w kampanię wyborczą partii rządzącej ${ }^{20}$. Kolejne przekazywane wiadomości donosiły o kontynuacji protestu wobec referendum, a nawet podawały informacje, że to Rosja wspiera jego przeprowadzenie ${ }^{21}$ - samo głosowanie, jak sugerowano w komunikacie, miałoby być prostą drogą do połączenia się z państwem serbskim. Spośród ponad miliona (1 219 399) uprawnionych do głosowania udział w referendum wzięło 680116 osób, co stanowi 55,67\% mieszkańców Republiki Serbskiej. W całej grupie głosujących 99,81\% opowiedziało się za świętem nawiązującym do prawosławnego kalendarza liturgicznego oraz do dnia proklamowania separatystycznej Republiki Serbskiej ${ }^{22}$. Valentin Inzko, austriacki dyplomata i polityk, pełniący od marca 2009 roku funkcję Wysokiego Przedstawiciela wspólnoty międzynarodowej dla Bośni i Hercegowiny, który na mocy porozumienia z Dayton ma szerokie uprawnienia w zakresie władzy ustawodawczej i wykonawczej w republice, powiedział, że referendum stanowi „,bezprecedensowy zamach na ład konstytucyjny w BiH”, a jego rezultaty nie będą mieć żadnej mocy prawnej ${ }^{23}$. Prezydent Republiki Serbskiej, poproszony przez prokuraturę na przesłuchanie do Sarajewa, zignorował wezwanie, twierdząc, że nie czuje się tam bezpiecznie, gdyż mógłby zostać zabity jak libijski przywódca Muammar Kaddafi ${ }^{24}$.

Problemem spornym, utrwalającym podział, a nawet segregację etniczną, zaprzeczając tym samym idei tożsamości wspólnotowej państwa, okazała się też decyzja o zmianach w szkolnictwie. W kantonie bośniackim przyjęto zasadę „,dwie szkoły pod jednym dachem”, według której każda z klas nauczałaby uczniów w ich etnicznym języku, tj. po serbsku, chorwacku i boszniacku, co prowadziłoby do separowania uczniów. Zjawisko to szerzy się w części zdominowanej przez Boszniaków i Chorwatów, wbrew opinii Federacyjnego Sądu Konstytucyjnego, że taka praktyka jest dyskryminująca ${ }^{25}$.

19 R. To e, Bosnian Serbs to Hold Referendum on Disputed Holiday, http://www.balkaninsight.com/en/ article/bosnian-serbs-to-hold-referendum-on-rs-national-holiday-07-15-2016?utm_source=Balkan+Transitional+Justice+Daily+Newsletter+-NEW\&utm_campaign=e202e6a5d2-RSS_EMAIL_CAMPAIGN\&utm_medium=email\&utm_term=0_a1d9e93e97-e202e665d2-319753701, (dostęp: 16.07.2016).

${ }^{20}$ Zob. też: M. Garaca Djurdjevic, Bosnian Serbs Divided over Controversial Referendum, http:// www.balkaninsight.com/en/article/bosnian-serbs-divided-over-controversial-referendum, (dostęp: 25.08.2016).

${ }^{21}$ M. Pantovic, D. Kovacevic, S. Lat a, Russia Lends Full Backing to Bosnian Serb Referendum, http:/www.balkaninsight.com/en/article/disputed-bosnian-serb-referendum-divides-russia-and-serbia, (dostęp: 23.09.2013).

${ }^{22}$ E. Rose, Bosnian Serb Referendum Results Questioned, http://www.balkaninsight.com/en/article/referendum-statistics-lack-oversight-say-analysts-as-turnout-figures-released, (dostęp: 26.09.2016).

${ }_{23}$ Serbowie będą mieli swoje święto? W BiH trwa liczenie głosów w kontrowersyjnym referendum, http:// wpolityce.pl/swiat/309641-serbowie-beda-mieli-swoje-swieto-w-bih-trwa-liczenie-glosow-w-kontrowersyjnym -referendum, (dostęp: 26.09.2016).

${ }^{24}$ E. Ro s e, D. Kov a c e vi c, Milorad Dodik: I Won't Be Safe in Sarajevo, http://www.balkaninsight.com/ en/article/dodik-i-won-t-be-safe-in-sarajevo-09-27-2016, (dostęp: 28.09.2016).

${ }^{25}$ R. To e, Bosnia's Segregated Schools Perpetuate Ethnic Divisions, http://www.balkaninsight.com/en/ article/bosnia-s-segregated-schools-perpetuate-ethnic-divisions-07-15-2016?utm_source=Balkan+Transitional+Justice+Daily+Newsletter+-+NEW\&utm_campaign=6834449b50-RSS_EMAIL_CAMPAIGN\&utm_medium=email\&utm_term=0_a1d9e93e97-6834449b50-319753701, (dostęp: 15. 07.2016). 
To kilka zaledwie przykładów z najnowszych dziejów Bośni i Hercegowiny, pokazujących, jak trudno zawrzeć kompromis pośród zróżnicowanych etnosów państwa, kiedy wyznacznikiem ich etnicznej przynależności pozostaje czynnik religijny bez względu na to, czy przedstawiciel danego narodu jest wierzący, czy pozostaje ateistą. W takim kontekście, w świetle prozy Emira Kusturicy i Miljenko Jergovicia, życie w Sarajewie z okresu wspólnego bytu przed wojną jawi się jako czas spokoju, kiedy choć istniały różnice etniczne, to jednak nie wpływały one na relacje międzyludzkie. Obaj autorzy przywracają pamięć o Sarajewie czasu pokoju, które łączyło ludzi we wspólnocie różnych kultur. Jak podobnie opisują swe sarajewskie życie i dorastanie obaj twórcy, bezwyznaniowość mieszkańców jugosłowiańskiego państwa pozostawała elementem, który miał je scalać. Ateizm państwowy na terenie Bośni i Hercegowiny, podobnie jak na przestrzeni całej Jugosławii, stanowił część polityki Komunistycznej Partii Jugosławii w latach 1945-1990. Jego wprowadzenie opierało się na założeniu, iż to różnice wyznaniowe podkreślają odmienności między etnosami, sprzyjają nacjonalizmowi, a nawet szowinizmowi, podkopując tym samym ideę braterstwa i jedności. Niemniej, jak przypomina Krzysztof Krysieniel:

wielowiekowy proces powstawania podziałów między wyznawcami prawosławia, islamu i katolicyzmu, wzmacniany od XIX wieku rodzącą się świadomością narodową dwóch najważniejszych na tym obszarze narodów - serbskiego i chorwackiego, zamknął drogę do budowy poczucia wspólnoty państwowej ${ }^{26}$.

Miljenko Jergović, uznawany za jednego z najwybitniejszych współczesnych pisarzy chorwackich, uhonorowany Literacką Nagrodą Europy Środkowo-Wschodniej Angelus, w swojej prozie wspomnieniowej, którą sam określa jako esej ${ }^{27}$, ukazuje proces kształtowania własnej tożsamości. Tłem jest opis dziejów jego rodziny o charakterze rozliczeniowym z chorwacką przeszłością w Bośni, wskazujący na obciążenie piętnem przeszłości ustaszów oraz chorwackim stosunkiem do Serbów. Autor snuje tę opowieść na bazie powikłanych losów poszczególnych jej członków - babć, ich licznych sióstr oraz ojca. Zarysowany w niej obraz oddaje zderzenie dwóch rzeczywistości - historycznej, związanej z dziejami jego rodziny na tle uwarunkowań ówczesnej Jugosławii oraz rzeczywistości po rozpadzie federacyjnego państwa i poszukiwania własnego miejsca $\mathrm{w}$ zmienionym świecie. Tematem przewijającym się na kartach utworu pozostaje kwestia tożsamości autora w nowych okolicznościach, kiedy tożsamość etniczna i narodowa, jak się okazuje na przykładzie losów pisarza, zderzyły się z poczuciem tożsamości wyznaniowej. Jergović, odnosząc się do uwarunkowań w byłej Jugosławii, zaznaczał, że to właśnie ateizm pozostawał „specyficznym nacjonalnym substratem naszych narodów”, a to, co naprawdę różni Chorwatów od Serbów czy Boszniaków od jednych i drugich, jest skromne i ubogie. Jak konstatuje ,,ateistom niewiele by pozostało z ich narodowości, gdyby jakimś cudem zapomnieli obyczaje i mity religii, z których pochodzą"28. Mimo ateizmu, który miał niwelować różnice etniczne i wyznaniowe pomiędzy mieszkańcami $\mathrm{BiH}$, o ich etnosie w ostatecznym rozrachunku decydowała pamięć o korzeniach swej wiary. Chorwackość

\footnotetext{
${ }^{26}$ K. Kry si en i e 1, Kryzys gospodarczy w Bośni i Hercegowinie..., s. 373.

${ }_{27}$ M. Jergović, Ojciec, s. 184.

${ }^{28}$ Ibidem, s. 128.
} 
Jergovicia, świadomość zakorzenienia, sprowadzająca się do pamięci o ojcu, „prawdziwym katolickim ateiście"29, stanowiły determinantę jego przynależności i tożsamości, która ostatecznie miała sprowadzać się do katolickości. Jak pisze:

kiedyś dawno katolickość stała się częścią chorwackiej tożsamości kulturowej, ale jest ona także częścią tych narodów i ludzi, którzy żyją wśród Chorwatów, a Chorwatami nie są. Prawie tak samo jak islam i prawosławie są częścią mojej tożsamości ${ }^{30}$.

Zwraca tym samym uwagę na wielokulturowość Sarajewa, wcześniejszą możliwość normalnych kontaktów międzyludzkich bez względu na pamięć wyznaniową jego mieszkańców, które ukształtowały go jako człowieka. Dlatego też imperatyw określenia swej przynależności religijnej, która miała stanowić podstawowy wyznacznik określający jego narodowość, kiedy w 1993 roku jako uchodźca przybył z okupowanego Sarajewa do Zagrzebia, postawił go przed problematycznym dla niego wyborem tożsamości. Jedynym wymaganym wówczas dokumentem, który mógłby potwierdzić narodowość, miała być metryka chrztu. Autor napotkał na liczne przeszkody administracyjne, gdyż nie tylko takiej metryki nie posiadał, jako że nie był ochrzczony, ale dodatkowo w dokumentach jego narodowość była określona jako jugosłowiańska. Jergović potwierdził tym samym, że w nowym miejscu i w zmienionych okolicznościach o jego narodowości decydowała konfesja. Zdobycie potrzebnych wpisów dla jej poświadczenia, nawet po znajomości, na pewnym etapie zakończyło się niepowodzeniem. Dopiero pomoc znajomego bośniackiego franciszkanina i chrzest w Kościele katolickim dały mu prawo bycia Chorwatem poza Bośnią i Hercegowiną ${ }^{31}$.

...pod koniec lat sześćdziesiątych i na początku siedemdziesiątych, Bóg w ich (dziadków i ojca, przyp. LMG) katolickim życiu, duszy i światopoglądzie był całkowicie nieobecny, a kraj, w którym mieszkali, wydawał się spokojny, wieczny i pewny, razem z ideologią rządzących, więc nikt nie mógł sobie nawet wyobrazić, że zaledwie za dwadzieścia parę lat wróci średniowiecze i świadectwo chrztu będzie określało całą tożsamość człowieka i odróżniało go od barbarzyńców, a Chorwacja, jak Iran i Izrael, będzie teokratyczną republiką, gdzie przynajmniej część mieszkańców prawo do obywatelstwa może zyskać wyłącznie dzięki wierze w przepisowego Boga. Gdyby moi dobrzy nono i nona coś takiego przeczuwali, ochrzciliby mnie bez fochów, bez narodowego i religijnego mizdrzenia się, i w katolickim kościele, i w prawosławnej cerkwi, i jeszcze daliby mnie obrzezaće ${ }^{32}$.

Prowokacyjne wyznanie pisarza wskazuje, że tak naprawdę przynależność narodowa, determinowana wyznaniem, nie ma dla niego większego znaczenia, a hipotetyczne dokonanie obrządków włączających do innych wspólnot religijnych dawałoby mu po prostu większe możliwości wyboru i określenia swej tożsamości.

Choć zauważalne jest podobieństwo losów Jergovicia i Kusturicy z okresu państwa jugosłowiańskiego, to jednak o kwestiach wiary i korzeniach etnicznej przynależności mówią zupełnie inaczej. Autobiografia Emira Kusturicy, której pierwsze wydanie ukazało się w 2010 roku pod tytułem nawiązującym do powiedzenia jego ojca, że „śmierć jest

\footnotetext{
29 Ibidem, s. 136.

${ }^{30}$ Ibidem, s. 139.

31 Ibidem, s. 136, 143-144.

${ }^{32}$ Ibidem, s. 153-154.
} 
niepotwierdzoną pogłoską" (Smrt je neprovjerena glasina) ${ }^{33}$, obrazuje proces świadomego poszukiwania własnej tożsamości i samoidentyfikacji etnicznej reżysera. Staje się też dokumentem zapisującym ten proces. Także Kusturica, jako mieszkaniec Bośni i Hercegowiny, uznawał się za Jugosłowianina. Jako obywatel federacji, tu chciał budować swoją przyszłość. Z racji sukcesów, jakie zdobywały jego filmy, i nabierającej rozpędu kariery międzynarodowej utożsamiał się z państwem jugosłowiańskim - tu przemieszkiwał, gdy powracał z Paryża, gdzie również mieszkał. Rozpad federacyjnego państwa i wojna w Bośni i Hercegowinie nakazały mu całkowitą weryfikację planów. Kolejne pobyty w Bośni, później w Czarnogórze, gdzie przeprowadziła się matka, skłaniały go do poszukiwania własnej tożsamości i próby odpowiedzi na pytanie, kim tak naprawdę jest. Autor wspomina o serbskim rodowodzie ojca, wzmiankując, że ten wraz ze swą siostrą Bibą, przyłączając się w latach wojny do Frontu Wyzwolenia Narodowego, zyskali przydomek ,szalonych Serbów" walczących z Niemcami ${ }^{34}$, natomiast w innym fragmencie wspomina o hercegowińskim pochodzeniu ojca. Przyjmuje więc i terytorialny, i etniczny wyznacznik swoich korzeni. Sam mówi o swoim serbskim pochodzeniu, utożsamiając się z tym etnosem jako zbiorowością. Sprzeciwia się też zjawisku obciążania Serbów winą za całe zło, jakie działo się na Bałkanach. Zwraca na to uwagę w jednej z licznych wypowiedzi, powracającej na łamach autobiografii, w której dokonuje porównania czasów minionych w Sarajewie z teraźniejszością. Zauważa przy tym, jak trudno zawrzeć porozumienie pomiędzy osobami, z którymi kiedyś celebrowało się wspólną kawę w sarajewskiej kawiarni:

...moje rodzinne miasto stało się jedynym miejscem na świecie, w którym nie ma już niezbędnych warunków do praktykowania pewnego ważnego rytuału. Chodzi o towarzyski zwyczaj, który odgrywał w moim życiu kluczową rolę. Mój jedyny poważny nałóg, wynikający z mojego orientalnego skrzywienia, nazywam „kawą porozumienia”. To spotkanie przy kawie z ludźmi, którzy podzielają wasz punkt widzenia (...). Podczas takiego spotkania toczą się ożywcze dyskusje, przy których jednak nie dochodzi do tarć. (...) Jeśli pewnego pięknego poranka jakimś cudem znalazłbym się w Sarajewie, poszedłbym na kawę do Šetalište. Żeby to było możliwe, konieczne byłoby owo porozumienie, o którym wspomniałem. Po to, żebyśmy nie podawali wszystkiego w wątpliwość. Sprawy mogłyby pozostać pod kontrolą dopóki, dopóty będziemy rozmawiać, jak na humanistów przystało, wymieniając opinie w stylu ,lubię wszystkie narody, nikogo nie nienawidzę, w każdym zbożu rosną chwasty” itp. Gdybym pijąc swoją kawę, zaryzykował i oświadczył, że liczne ofiary padły po obu stronach, zarówno porozumienie, jak i kawa wylądowałyby na podłodze. Dla Serbów nie ma amnestii: to my, Serbowie, wymyśliliśmy tę wojnę, i wszystkie pozostałe zresztą te $\dot{z}^{35}$.

Jak ze smutkiem konstatuje, porozumienie ponad podziałami - „kawa porozumienia" - przestało istnieć, gdyż nierealne stało się prowadzenie dialogu, w którym rozmówcy mogliby wyrażać odmienne opinie.

Na kartach obu utworów spotykamy podobne elementy biografii członków rodziny. Jednym z nich jest manifestowana duma z wysokiego poziomu edukacji swoich przodków. Obaj autorzy powołują się bowiem na tradycję nauki w słynnej jezuickiej szkole w Trawniku, którą kończyli w różnych okresach jej funkcjonowania ich antenaci. Kusturica

\footnotetext{
${ }^{33}$ E. Ku s turi ca, Gdzie ja jestem w tej historii?, s. 385.

34 Ibidem, s. 294.

35 Ibidem, s. 362-364.
} 
wspomina, że ojciec pobierał nauki w liceum chrześcijańskim w Trawniku ${ }^{36}$, natomiast Jergović odnotowuje, że ojciec jego matki uczył się gimnazjum jezuickim ${ }^{37}$. Ciesząca się renomą szkoła trawnicka, prowadzona przez jezuitów, z jednej strony pozostaje przedmiotem dumy, z drugiej zaś autorzy wskazują, że pobieranie tam nauki - podobnie jak w przypadku wielu innych mieszkańców BiH, którzy się w niej uczyli - nie uchroniło ich przed ateizmem. Kusturica określa, że jego ojciec „nabrał dystansu do ideologii religijnej”, a zapamiętana w trakcie nauki modlitwa Ojcze nasz, choć tkwiła w pamięci, to służyła Muratowi Kusturicy jedynie za czasomierz do odmierzania minut, by ugotować jajko na miękko ${ }^{38}$. Natomiast dziadek Jergovicia, mimo że chodził do tej szkoły, „urodził się jako dziecko niewierzący" 39 .

Kusturica w swej fabularyzowanej biografii zwraca uwagę na istnienie poczucia odrzucanej w dobie państwa Tity wyznaniowości. Poświęcając nieco miejsca stosunkowi ojca, aparatczyka w dziale informacji, do osiągnięć Tity, uznawanego przez Murata i Emira za uzurpatora i „bolszewickiego monarchę"40, stawia pytania nachodzące go w trakcie wojny o własną tożsamość. To one przyczyniły się do dalszych poszukiwań genealogii swoich przodków oraz próby odpowiedzi na pytanie, „kim my jesteśmy”/ „kim jestem”. Dalsze losy Kusturicy, zapoczątkowane przez pytania stawiane w autobiografii, już poza nią przyniosły odpowiedź na problematyczną kwestię jego przynależności. Wychowany zgodnie z duchem czasów jugosłowiańskich jako bezwyznaniowiec, dorastał w świeckiej rodzinie muzułmańskich Serbów ${ }^{41}$. Wątpliwości związane z przewijającym się w autobiografii pytaniem, stawianym przez jego matkę - „do kogo należysz synu” oraz twierdzenia ojca ateisty, który miał zwykle mówić, że są Serbami - prowadziło Kusturicę do poszukiwania dowodów swej serbskiej tożsamości i korzeni przodków w bibliotekach i archiwach. Według odnalezionych przez niego materiałów w trakcie kwerend genealogicznych, Kusturiciowie przed wiekami mieli być prawosławnymi Serbami, którzy w dobie panowania osmańskiego przeszli na islam ${ }^{42}$. Wiara stawała się dla reżysera istotnym elementem jego tożsamości. Dał temu wyraz jeszcze w trakcie mowy wygłoszonej podczas wręczenia mu nagrody AVNOJ, twierdząc, że to ona nadawała sens istnieniu, czy to w kategoriach społecznych, czy osobistych:

...odrzucam możliwość całkowitego porzucenia wiary w cokolwiek. Bo być bez wiary, to znaczy - tak przynajmniej twierdzą Ewangelie - nie istnieć. Wyświadczam więc sobie samemu małą przysługę i wyrażam niniejszym swoje pragnienie, by wierzyć i mimo wszystko... mieć nadzieję ${ }^{43}$.

36 Ibidem, s. 295.

37 M. Jergović, Ojciec, s. 145.

${ }^{38}$ E. Kusturic a, Gdzie ja jestem w tej historii?, s. 295.

${ }^{39}$ M. Jergović, Ojciec, s. 145.

${ }^{40}$ E. Kus turi ca, Gdzie ja jestem w tej historii?, s. 336-337.

${ }^{41}$ Kwestią marginalną pozostaje pozaetniczne określanie jego pochodzenia przez badaczkę dzieł filmowych Kusturicy do roku 2005, która sprowadzała jego pochodzenie do stwierdzenia: „średniozamożna rodzina muzułmańska”. Zob. M. J a n kow s k a, Świat według Emira Kusturicy. Próba monografii twórczości, Poznań 2004, s. 11.

${ }^{42}$ D. Halpern, The (Mis)Directions of Emir Kusturica, ,, The New York Times Magazine” 2005, MAY 8, Źródło: http://www.nytimes.com/2005/05/08/magazine/the-misdirections-of-emir-kusturica.html, (dostęp: 18.08.2016).

${ }^{43}$ E. Kusturica, Gdzie ja jestem w tej historii?, s. 237. 
W rezultacie w roku 2005, w dzień św. Jerzego, Emir Kusturica przyjął chrzest w Serbskiej Cerkwi Prawosławnej, przyjmując imię serbskiego władcy i świętego, Nemanija. Dla krytyków, nie tylko jego filmów, stało się to dowodem, iż zdradził swoje bośniackie korzenie.

Z kolei Jergović, faktycznie zmuszony do chrztu w Kościele katolickim, gdyż stanowiło to bezwzględny wymóg formalny potwierdzający jego przynależność narodową, nadal pozostał ateistą. Jak wspomniał, jego tożsamość została zdeterminowana przez sarajewską przeszłość, tym samym określanie własnej etniczności poprzez religię stanowi zaprzeczenie logiki. Pamięć o minionych losach pisarza pozostaje dla niego „wieczną konfrontacją z tożsamościami" ${ }^{44}$. Dla Jergovicia także stosowany alfabet okazał się dowodem przynależności do chorwackiego etnosu: „W czasach wspólnego, dwuwariantowego języka pisałem i mówiłem, tak jak dziś, nieortodoksyjnym wariantem zachodnim. Pisałem więc po chorwacku"45.

Obaj autorzy, wywodzący się z Sarajewa epoki Tity, w swoich wspomnieniach zwracają uwagę na podziały, jakie zaistniały pośród ich rodzin i bliskich jeszcze w wyniku następstw II wojny światowej. Czas względnego spokoju kształtował w nich myślenie o wspólnocie miejsca, z którego się wywodzą, i funkcjonowania w wieloetnicznym i zróżnicowanym kulturowo społeczeństwie w atmosferze przedwojennego Sarajewa, a przemieszana tożsamość była zarówno serbska, chorwacka, jak i bośniacka. Decydowała o niej tożsamość wspólnotowa miejsca, w którym się urodzili i rozwijali. Rozpad Jugosławii, zwieńczony krwawą wojną w Bośni i Hercegowinie, wymusił na nich konieczność indywidualnego samookreślenia, którego miernikiem i wyznacznikiem stała się - postrzegana nie tylko stereotypowo, ale jak dowodzą tego losy obu twórców, także w praktyce - przynależność konfesyjna, która Chorwatów trwale wiąże z katolicyzmem, a Serbów z prawosławiem.

\section{Bibliografia}

Literatura podmiotu:

Jergović M., Ojciec, tłum. M. Petryńska, Wołowiec 2012.

Kusturica E., Gdzie ja jestem w tej historii, tłum. G. Hałat, M. Goreń, Warszawa 2014.

Monografie:

Bokszański Z., Tożsamości zbiorowe, Warszawa 2006.

Czermiński M., Z podróży po Bośni i Hercegowinie, Kraków 1899.

Jankowska M., Świat wedtug Emira Kusturicy. Próba monografii twórczości, Poznań 2004.

Krysieniel K., W cieniu Dayton. Bośnia i Hercegowina między etnokracja i demokracja konsocjonalna, Warszawa 2012.

Ługowska D., Zasada trójzgodności. Analiza kontekstowa treści pojęcia jedność, Warszawa 2013. Muś J., Bośnia i Hercegowina. Etnopolityczne podziały i ich uwarunkowania, Lublin 2013.

Prószyński L., Bośnia i Hercegowina. Treściwe opisanie tych krajów pod względem topograficznym, etnograficznym, statystycznym i historycznym. Przyczynek do ziemioznawstwa pobratymczych nam ludów poludniowo-zachodniej Stowiańszczyzny, Warszawa 1882.

${ }^{44}$ M. Jergović, Ojciec, s. 205.

45 Ibidem, s. 137. 
Sierotwiński S., Słownik terminów literackich, Wrocław-Warszawa 1986.

Wybranowski D., Między niepodległością a dezintegracją. Bośnia i Hercegowina w XX i XXI wieku, Szczecin 2011.

Artykuły:

Batowski H., Problem bośniacki - Podstawy historyczne, „Prace Komisji Środkowoeuropejskiej”, PAU, 1994, t. II, s. 21-37.

Czapik-Lityńska B., Etniczny wymiar ponowoczesnej tożsamości kulturowej, [w:] Czytać. Wędrować. Być. Tom dedykowany Profesorowi Zdzisławowi Daraszowi, red. M. Bogusławska, J. Goszczyńska, J. Šuler-Galos, Warszawa 2016, s. 113-124.

Ilić J., Characteristics and Importance of some Etno-national and Political-geografic factors relevant for the possible political-legal disintegration of Yugoslavia, [w:] The creation and changes of the internal borders of Yugoslavia, red. S. Ivanović, Belgrad 1991, s. 69-94.

Jagiełło-Szostak A., Komuniści jugosłowiańscy wobec idei i tożsamości jugosłowiańskiej, „Balcanica Posnaniensia”, 2013, t. XX, s. 185.

Krysieniel K., Kryzys gospodarczy w Bośni i Hercegowinie i jego wplyw na stabilność państwa (wybrane aspekty), [w:] Bałkany Zachodnie w systemie bezpieczeństwa euroatlantyckiego, red. A. Głowacki, S. L. Szczesio, Łódź 2015, s. 439-458.

Moroz-Grzelak L., Emblematyczne formy manifestowania wartości w świecie postjugostowiańskim. Patriotyzm, [w:] Konstrukcje i destrukcje tożsamości. Wartości w świecie słowiańskim, red. E. Golachowska, D. Pazio-Wlazłowska, Warszawa 2015, s. 363-364.

Moroz-Grzelak L., Polska wizja bałkańskiej przestrzeni terytorialnej w kontekście pojęcia „kociot bałkański”, „Slavia Meridionalis”, 2007, t. 7, s. 168-169.

Spahić V., Bośniacko-muzulmańska tożsamość kulturowa między zasadami mocy i pokoju, [w:] Wokót Macedonii: siła kultury - kultura sity, red. B. Zieliński, Poznań 2002, s. 221, 229.

M. Savić-Bojanić, Minority Discontent as an Internal Destabilization Factor: The Issue of Territorial Minorities in Bosnia and Hercegovina, [w:] Batkany Zachodnie w systemie bezpieczeństwa euroatlantyckiego, red. A. Głowacki, S. L. Szczesio, Łódź 2015, s. 459-483.

Timofiejuk P., Ustrój polityczny Republiki Bośni i Hercegowiny w myśl porozumień z Dayton, [w:] Bałkany. Etnokulturowe podtoże konfliktów, red. W. Konarski, A. Koseski, Pułtusk 2006, s. $147-186$.

Źródła internetowe:

Garaca Djurdjevic M., Bosnian Serbs Divided over Controversial Referendum, http://www.balkaninsight.com/en/article/bosnian-serbs-divided-over-controversial-referendum (dostęp 25.08.2016).

Halpern D., The (Mis)Directions of Emir Kusturica, „,The New York Times Magazine”, MAY 8, 2005, http:/www.nytimes.com/2005/05/08/magazine/the-misdirections-of-emir-kusturica.html (dostęp 18.08.2016)

Plagijat ili ne, http://www.avaz.ba/clanak/249336/himna-bih-predmet-sprdnje-na-americkim-socijalnim-mrezama?url=clanak/249336/himna-bih-predmet-sprdnje-na-americkim-socijalnimmrezama. (dostęp 20.08.2016).

Pantovic M., Kovacevic D., Lata S., Russia Lends Full Backing to Bosnian Serb Referendum, http:// www.balkaninsight.com/en/article/disputed-bosnian-serb-referendum-divides-russia-and-serbia (dostęp 23.09.2013).

Rose E., Bosnian Serb Referendum Results Questioned, http://www.balkaninsight.com/en/article/referendum-statistics-lack-oversight-say-analysts-as-turnout-figures-released (dostęp 26.09.2016).

Rose E., Kovacevic D., Milorad Dodik: I Won't Be Safe in Sarajevo, http://www.balkaninsight.com/ en/article/dodik-i-won-t-be-safe-in-sarajevo-09-27-2016 (dostęp 28.09.2016). 
Serbowie będa mieli swoje święto? W BiH trwa liczenie głosów w kontrowersyjnym referendum, http://wpolityce.pl/swiat/309641-serbowie-beda-mieli-swoje-swieto-w-bih-trwa-liczenie-gloso w-w-kontrowersyjnym-referendum, (dostęp 26.09.2016).

Toe R., Bosnia's Segregated Schools Perpetuate Ethnic Division, http://www.balkaninsight.com/en/ article/bosnia-s-segregated-schools-perpetuate-ethnic-divisions-07-15-2016?utm_source=Balkan+Transitional+Justice+Daily+Newsletter+-+NEW\&utm_campaign=6834449b50-RSS EMAIL_CAMPAIGN\&utm_medium=email\&utm_term=0_a1d9e93e976834449b50-319753701. (dostęp 15. 07.2016).

Toe R., Bosnian Serbs to Hold Referendum on Disputed Holiday, http://www.balkaninsight.com/ en/article/bosnian-serbs-to-hold-referendum-on-rs-national-holiday-07-15-2016?utm source $=$ Balkan + Transitional + Justice + Daily + Newsletter + -NEW\&utm_campaign $=$ e202e6a5d2-RSS_EMAIL_CAMPAIGN\&utm_medium=email\&utm_term=0_a1d9e93e97e202e6a5d2-319753701 - (dostęp 16.07.2016).

\section{Lilla Moroz-Grzelak}

\section{The Search for the Identity of the Community and Ethnic Self-Identification of the Inhabitants of Bosnia and Herzegovina in Light of the Literature}

\section{Summary}

The article, based on the autobiographical texts of the writer Milenko Jergovic and director Emir Kusturica, shows issues of cultural self-identification with which artists born in Sarajevo met after the war in Bosnia and Herzegovina. The consequence of these events was the necessity of seeking their own identity in new environments and new places (Croatia, Serbia).

To better illustrate the problems of determining Jergovic's and Kusturica's own identity, there are references not only to the time of Tito's Yugoslavia, when the doctrine of brotherhood and unity was set upon all citizens, along with the state atheism, but also to the situation in the country after the conclusion of the Dayton agreement. This background led to the numerous problems of a multicultural state that prevented the full stabilization of the country, and made it impossible to form a common, national identity. The analysis of selected autobiographical motifs allowed a complex picture of Bosnia and Herzegovina - the state, which is facing many seemingly unsolvable problems to be presented. It generates not only a multi-ethnic society with different religious traditions, like Catholicism for Croats and Orthodox Church for Serbs, but in the same time the lack of agreement in the symbolic sphere, relating to the state symbols, which are the emblem, flag and anthem, that would be acceptable to all nationalities within the country.

Keywords: ethnic identity, national identity, Bosnia and Herzegovina, Emir Kusturica, Miljenko Jergović. 